
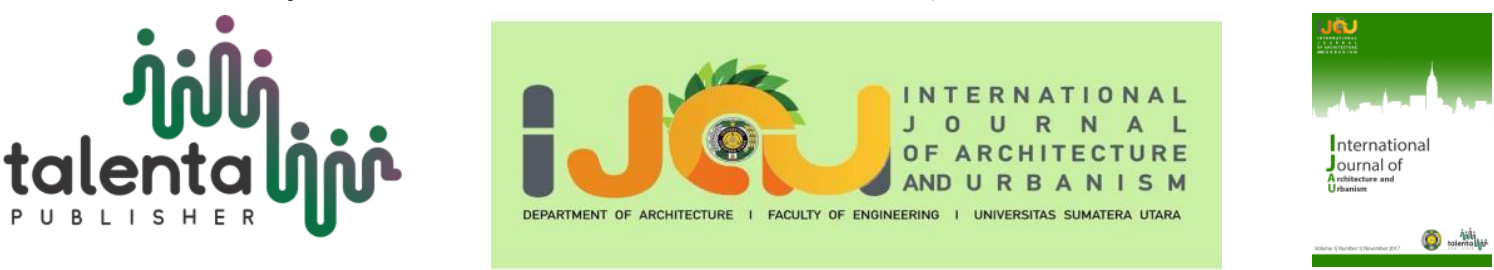

\title{
Spatial Structure of The Leisure Zone in The Pangururan District Urban Waterfront
}

\author{
Erni Triska ${ }^{*}$ \\ ${ }^{1}$ Independent Researcher, Medan, Indonesia
}

\begin{abstract}
Pangururan is a district in Samosir regency, north sumatera province, Indonesia. Pangururan also the capital city of samosir regency and pangururan district capital is Pasar Pangururan. In Indonesian population census 2020, Pangururan has 34.209 population. Samosir regency residents mostly Batak Toba tribe and some are Batak Angkola, Batak Simalungun, Batak Karo tribe and immigrant from Java, Minangkabau, and Nias that are mostly resides in the capital city. Residents of Pangururan commonly farming for living. And for the residents who lived near the shore of the lake are mostly fisherman. Now, Pangururan waterfront area is included in an area arrangement project called Waterfront City Pangururan (WCP). WCP is a part from Program Pembangunan Pariwisata Terintegrasi dan Berkelanjutan (P3TB) for Lake Toba destinantion of tourism and promoting Lake Toba as $K S P N$. There are many leisure zones in Pangururan District Urban Waterfront that changes the spatial structure of Pangururan. This research uses qualitative method. The aim of this research is to find identification from the effect of tourism toward pattern and spatial structure in Pangururan Waterfront Area is needed.
\end{abstract}

Keyword: leisure zone, Pangururan waterfront, spatial structure

Received 17 September 2021 | Revised 19 October 2021 | Accepted 25 October 2021

\section{Introduction}

In recent centuries, this area of the city that often sits on the riverbank has been mainly used for ports and industry. Since the 1960s, the waterfront has returned to spatial significance by being realized as an urban design resource, increasing waterfront tourism attracting industrial, business, office, and residential use to ensure maximum protection. Most of the people can enjoy the quality of seaside products and the welfare of the people in a fair and equitable manner [1].

The waterfront is an interaction zone between the waters and the urban development area [2]. Literally, waterfront can be interpreted as an area or area located on the edge of the water [3],

\footnotetext{
*Corresponding author at: Menteng VII Street, Medan, Indonesia

E-mail address: ernitriska9@gmail.com
}

Copyright (C 2021 Published by Talenta Publisher, ISSN: 2622-0008 e-ISSN: 2622-1640 | DOI: 10.32734/ijau.v5i3.7460

Journal Homepage: https://talenta.usu.ac.id/ijau 
including the water catchment area between land and water areas (beach/river/lake) which is a place for the activities of the surrounding community [4].

The development of waterfront areas is able to include human values for the needs of public spaces and natural values in them [5]. Waterfront development basically organizes urban areas located on the water's edge and changes orientation towards the water. Changes in the orientation of urban development towards the waters can improve the quality of the waters themselves [6]. The existence of a waterfront provide a comfortable place not only for tourists to visit but also as a place to live for its citizens [7].

In connection with the construction of a waterfront on the banks of the river, the process of social interaction of community members becomes more meaningful, this happens because of the unity of the community in developing the management of the seaside area together. The result of this development is that it has visual and physical contact with the air which is part of the efforts to develop urban areas by physically adjacent to the air as well as the form of development in water areas. Pangururan is a district in Samosir regency, north sumatera province, Indonesia. Some parts of Pangururan Di Residents of Pangururan commonly farming for living. And for the residents who lived near the shore of the lake are mostly fisherman. Now, Pangururan waterfront area is included in an area arrangement project called Waterfront City Pangururan (WCP). WCP is a part from Program Pembangunan Pariwisata Terintegrasi dan Berkelanjutan (P3TB) for Lake Toba destination of tourism and promoting Lake Toba. In order to boost tourism in Danau Toba, therefore there are various leisure zones in Pangururan Waterfront. These leisure zones may have changed the spatial structure of Pangururan especially Pangururan Urban District Waterfront.

\section{Literature Review}

Land use in a city reflects the land development of a city [8]. This land development usually creates the spatial structure of a city. This spatial structure also reflects the characteristics of a land. Spatial structure also arrange the settlement center and a network system of infrastructures that support the socio-economic activities of the community [9]. Spatial structures classified into three based on city service center which are Monocentric city, Polycentric city and metropolitan city. Monocentric city is where the city has not developed rapidly, the population is not much, and only has one service center (CBD) [10]. Polycentric city is when the city grow bigger and has more than one service center and last one is Metropolitan city is a large city surrounded by satellite cities that quite far apart from the urban fringe, but all of them form a unified system in the service of residents of the metropolitan area. Based on the service centers, the spatial structure model is divided into four which are : Mono centric, consisting of one center and several sub-centers that are not interconnected between one sub-center and other subcenters, Multi-nodal, consisting of one center, several sub-centers and sub-centers that are 
connected to each other and some are not connected. Then, Multi center, consisting of several centers, sub centers and sub centers that are connected to each other. And last, not centralized means there is no center. All nodes have the same hierarchy and are connected to each other [11].

City development only happen if the road network available, the exsisting condition is built, and access to city center. The growth of an area that built is affected by the distance to city center. the growth implied to the development and density that happen faster inside an around city center [12][13].

Recreation is defined as refreshment of body and mind; something that brings joy and freshen like entertainment, picnic and many more. Recreation is an active and positive activity that done as free and as creative as possible in a spare time as distraction from daily work based on hobbies and talents [14]. Recreation must have actors and activities. The actors in recreation area are: (a) visitors that divided into two; common visitors that come with recreation purpose like relaxing, enjoying the objects and tourism fasilities without other special purpose and special visitors that come with other purpose or recreation is not their main purpose; (b) the manager is the person who is responsible for the success of an event in a amusement park, and maintain every operational activity of the amusement park; (c) local communitites. The presence of local community of the area, mostly as street vendors that sells stuff the visitors of amusement park needed. Activities in a recreation area that is part of tourism area are divided into four activities; a) recipient, activities that mainly receiving tourists both from local and international. B) visitors, including activities that visitors usually do in recreational area for recreational activities. C) management, including the managers activity managing the recreation area and serving the visitors who come to the recreation area d) supporting activities are activites that support the main activities of the visitors in the recreation area. Through this literature review, it is concluded that the recreation area must have four activites, three actors and place or area to provide entertainment for everyone [14][15].

\section{Method}

The purpose of this research is to identify the affect of tourism/leisure activities toward pattern and spatial structure that formed. Therefore, qualitative method is used in this research. The research focus on finding tourism activities in pangururan waterfront area and observing the influence on the structure Pangururan city. Below is Pangururan District as seen on map (Figure $1)$. 


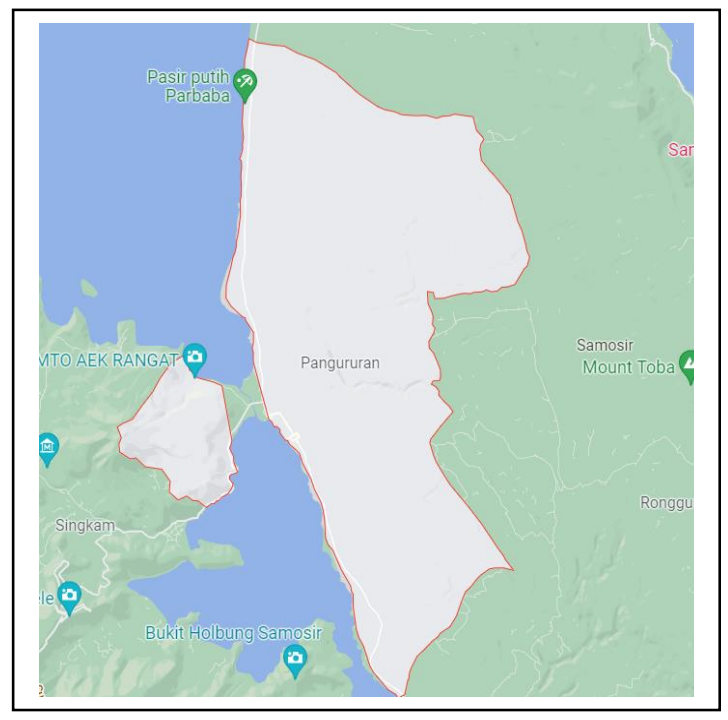

Figure 1 Pangururan

This research location started from Simanindo Street to Simbolon Purba street, also Pangururan to Tele-Pangururan and Tano Ponggol Bridge.

\section{Results and Discussion}

Leisure zone is an area that provides entertainment and fulfills the components of the leisure zone found in literature studies. Based on the results of observations found leisure zone points and also found points that have the potential as leisure zones. There are six leisure zones that found during observation (Figure 2).

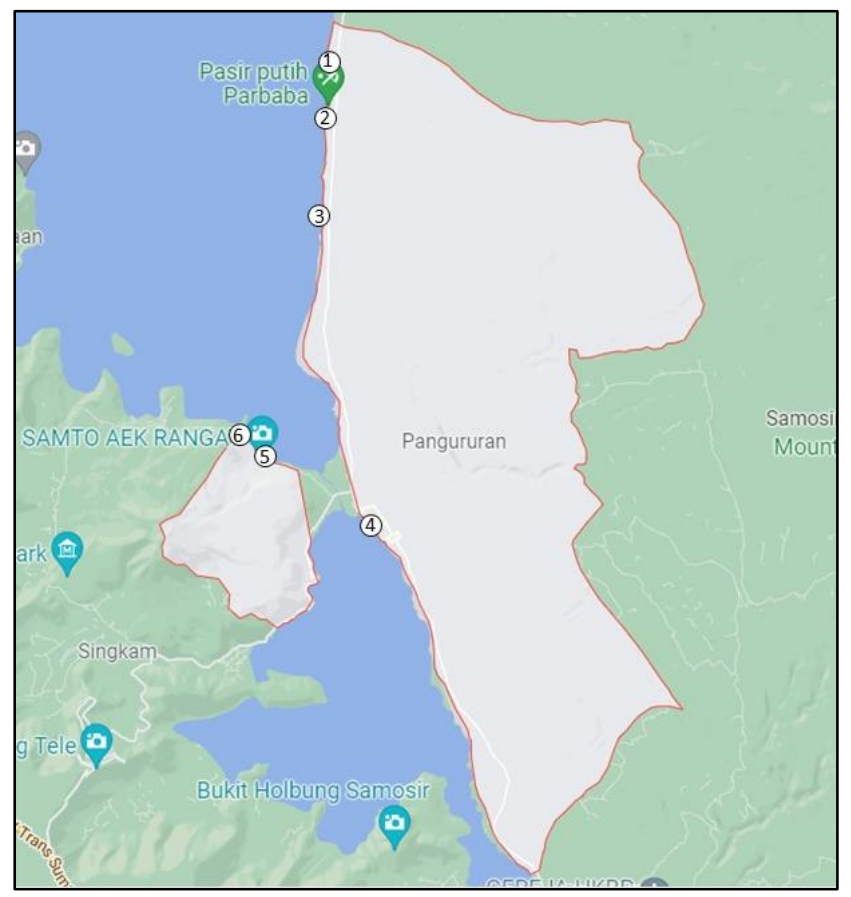

Figure 2 Leisure Zones in Pangururan District Urban Waterfront 
These leisure zones are 1) Dermaga Jetty and Restaurant, 2) Pantai Pasir Putih Parbaba, 3) Fishing Area, 4) Taman Reklamasi, 5) Menara Doa Sinatapan, and 6) Samto Aek Ranga. Also along the waterfront area are filled with restaurant or local coffee shop or even motel and inn.

Most of this leisure zones have match the components of leisure zones, which are healing, community based, has owner and visitors. Because of these leisure zones, there are lots of visitors would come and visit Pangururan Pangururan District Urban Waterfront so that the spatial structure of Pangururan oriented to Pangururan District Urban Waterfront that means nodes have the same hierarchy and are connected to each other. Therefor, it shows that the development of Pangururan is not only oriented to the center but also other districts.

\section{Conclusion}

The leisure zones along Pangururan District Urban Waterfront have attracted many visitors that change the spatial structure of Pangururan. This shows that Pangururan District Urban Waterfront have potention to be developed and help the government to attract more visitors to visit Danau Toba.

\section{REFERENCES}

[1] N. Hasriyanti, "Kajian Ruang Publik Tepi Air," Vokasi, Th. X, No. 1. 2014.

[2] A. B. Yassin, S. Bond, J. McDonagh, "Developing Guidelines for Riverfront Developments for Malaysia," Pacific Rim Property Research Journal, Vol. 17, no. 4, pp.511-530. 2011.

[3] D. J. Tangkuman, L. Tondobala, "Arsitektur Tepi Air (Waterfront Architecture)," Jurnal Media Matrasain, Vol. 8, no. 2, pp.50-54. 2011

[4] I. D. Puspita, I. S. Fatimah, A. Gunawan, "Evaluasi Lanskap Situ-Front Sebagai Pengembangan Waterfront di Kawasan Cibinong Raya, Kabupaten Bogor," Jurnal Lanskap Indonesia, Vol. 9, no. 1, pp.13-23. 2017

[5] R. E. Pramesti, "Sustainable Urban Waterfront Redevelopment : Challenge and Key Issues," vol. 14, no. 2, pp.41-54. 2017.

[6] B. O. Y. Marpaung, F. K. Rambe, "Kajian Perancangan Tepi Air Dalam Mendukung Desa Nainggolan Sebagai Tujuan Wisata," Talenta Conference Series : Energy and Engineering (EE), vol. 3, no. 1. 2020.

[7] B. E. S. Lagarense, "Evaluating Waterfront Uses for Tourism and Recreation with Acceptance to Changes: The Case of Manado Waterfront Development," Journal of Business Review, vol. 3, no. 1, pp.122-144. 2013.

[8] C. Zhong, S. M. Arisona, X. Huang, M. Batty, G. Schmitt, "Detecting the Dynamics of Urban Structure through Spatial Network Analysis," International Journal of Geographical Information Science, vol. 20, no. 11, pp.2178-2199. 2014.

[9] C. Zhong, M. Schläpfer, S. M. Arisona, M. Batty, C. Ratti, G. Schmitt, "Revealing Centrality in the Spatial Structure of Cities from Human Activity Patterns," Urban Studies, vol. 54, no. 2, pp.437-455. 2017.

[10] B. Setiawan, I. Rudiarto, "Kajian Perubahan Penggunaan Lahan dan Struktur Ruang Kota Bima,” Jurnal Pembangunan Wilayah dan Kota, vol. 12, no.2, pp. 154-168. 2016.

[11] Karolien, Vermeiren, et al, "Urban Growth of Kampala, Uganda: Pattern Analysis and Scenario development," Elsevier: Landcape and Urban Planning, vol. 106, p. 199-206. 2016.

[12] Oduro, K. Ocloo, C. Peprah, "Analyzing Growth Patterns of Greater Kumasi Metropolitan Area Using GIS and Multiple Regression Techniques," Journal of Sustainable Development, vol. 7, no. 5, pp. 13. 2014. 
[13] X. Liu, C. Kang, L. Gong, Y. Liu, "Incorporating Spatial Interaction Patterns in Classifying and Understanding Urban Land Use," International Journal of Geographical Information Science, vol. 30, no. 2, pp. 334-350. 2016.

[14] Ismayanti, Pengantar Pariwisata, Jakarta:Grasindo, 2011.

[15] J. M. Latif, I. Arif, L. S. Mulyawati, "Pengembangan Ruang Kawasan Tepi Pantai untuk Rekreasi dalam Mendukung Kota Ternate Sebagai Waterfront City," vol. 1, no. 1. 2020. 